\title{
Genetic population structures of the blue starfish Linckia laevigata and its gastropod ectoparasite Thyca crystallina
}

\author{
M. Kochzius ${ }^{1, *},{ }^{* *}$, C. Seidel ${ }^{1,2}$, J. Hauschild ${ }^{1,3}$, S. Kirchhoff ${ }^{1}$, P. Mester ${ }^{1}$, \\ I. Meyer-Wachsmuth ${ }^{1}$, A. Nuryanto ${ }^{1,4}{ }^{,}$J. Timm $^{1}$ \\ ${ }^{1}$ Biotechnology and Molecular Genetics, FB2-UFT, University of Bremen, Leobenerstrasse UFT, 28359 Bremen, Germany \\ ${ }^{2}$ Present address: Insitute of Biochemistry, University of Leipzig, Brüderstrasse 34, 04103 Leipzig, Germany \\ ${ }^{3}$ Present address: Friedrich-Loeffler-Institut, Bundesforschungsinstitut für Tiergesundheit, Institut für Nutztiergenetik, \\ Höltystrasse 10, 31535 Neustadt, Germany \\ ${ }^{4}$ Present address: Faculty of Biology, Jenderal Soedirman University, Dr. Suparno Street, Purwokerto 53122, Indonesia
}

\begin{abstract}
Comparative analyses of the genetic population structure of hosts and parasites can be useful to elucidate factors that influence dispersal, because common ecological and evolutionary processes can lead to congruent patterns. We studied the comparative genetic population structure based on partial sequences of the mitochondrial cytochrome oxidase I gene of the blue starfish Linckia laevigata and its gastropod ectoparasite Thyca crystallina in order to elucidate evolutionary processes in the Indo-Malay Archipelago. AMOVA revealed a low fixation index but significant genetic population structure $\left(\phi_{\mathrm{ST}}=0.03\right)$ in $L$. laevigata, whereas $T$. crystallina showed panmixing $\left(\phi_{\mathrm{ST}}=0.005\right)$. According to a hierarchical AMOVA, the populations of L. laevigata could be assigned to the following groups: (1) Eastern Indian Ocean, (2) central Indo-Malay Archipelago and (3) Western Pacific. This pattern of a genetic break in L. laevigata between the Indian and Pacific Ocean, congruent to studies on other marine species in the Indo-Malay Archipelago, is likely due to allopatry caused by Pliocene and Pleistocene glacial sea level low stands.
\end{abstract}

KEY WORDS: COI · Coral Triangle $\cdot$ Coral reef $\cdot$ Phylogeography $\cdot$ Population expansion $\cdot$ Southeast Asia

Resale or republication not permitted without written consent of the publisher

\section{INTRODUCTION}

Comparative analyses of the genetic population structure of a host and its parasite can be used to elucidate factors that influence dispersal (Criscione 2008), because common ecological and evolutionary processes can lead to congruent patterns (Bermingham \& Moritz 1998, Avise 2000). The blue starfish Linckia laevigata (Ophidiasteridea; Chao 1999) is widely distributed on Indo-Pacific coral reefs, from the Western Indian Ocean across the Indo-Malay Archipelago to southeastern Polynesia (Yamaguchi 1977). It is frequently parasitised by the obligate and strictly specific ectoparasitic gastropod Thyca crystallina (Eulimidae;
Warén 1980, Janssen 1985), which penetrates the radial hemal and perihemal system of $L$. laevigata with its proboscis to obtain nutrients (Egloff et al. 1988). T. crystallina seems to be co-distributed with its host, ranging from the Western Indian Ocean across the Indo-Malay Archipelago and northeastern Australia to Samoa and Fiji (Sloan et al. 1979, Warén 1980). Infection rates of $L$. laevigata with $T$. crystallina vary among populations, ranging from $14.3 \%$ in Fiji (Egloff et al. 1988), $15.7 \%$ (Troncoso \& Van Goethem 1998) and $22.3 \%$ (Bouillon \& Jangoux 1984) in eastern New Guinea to $62.0 \%$ in the Moluccas (Elder 1979).

Here we compare the genetic population structure of the host Linckia laevigata and its parasite Thyca 
crystallina in the Indo-Malay Archipelago. This highly dynamic region in terms of biodiversity, ecology, geology and oceanography is the centre of marine shallow water biodiversity (Briggs 1999, Hoeksema 2007). Molecular phylogenetic studies have shown a break between the Indian and Pacific Oceans, e.g. in lionfishes (Kochzius et al. 2003), clownfishes (Timm et al. 2008), and damselfishes (Froukh \& Kochzius 2008). Additionally, a growing number of population genetic studies in the Indo-Malay Archipelago show a complex pattern of divergent lineages and restricted gene flow, e.g. in a clownfish (Timm \& Kochzius 2008), giant clams (Kochzius \& Nuryanto 2008, Nuryanto \& Kochzius 2009), and a mushroom coral (Knittweis et al. 2009).

Plate tectonic movements in the Indo-Malay Archipelago and global fluctuation of sea level during multiple Pliocene and Pleistocene glaciations are the primary hypothesised triggers for this genetic separation of the 2 ocean basins. Most of the islands in the IndoMalay Archipelago did not exist or were not at their current position about 30 million years ago. During that time, water masses of the Pacific South Equatorial Current (SEC) entered the Indian Ocean via the socalled Indonesian seaway. This current pattern started to change about 25 million years ago, due to the development of Sulawesi by the amalgamation of several fragments and the northward movement of New Guinea, the Bird's Head Peninsula, and Australia (Hall 1998). The Indonesian seaway was finally closed about 5 million years ago by the northward displacement of New Guinea (Cane \& Molnar 2001). Since then, the major exchange of water masses between the 2 oceans has been facilitated by the Indonesian throughflow (ITF), which originates from the northern Pacific (Gordon \& Fine 1996, Gordon 2005).

Additionally, multiple glaciations in the Pliocene and Pleistocene caused global fluctuations in sea level with low stands of up to $120 \mathrm{~m}$ below present sea level (Krantz 1991, Rohling et al. 1998, Siddall et al. 2003). Shallow shelf areas such as the Sunda shelf were exposed, and ocean basins were separated (Voris 2000; Fig. 1). Molecular clock estimates support the view of allopatric speciation in separate ocean basins during the Pliocene and Pleistocene in some species (Kochzius et al. 2003, Timm et al. 2008).

The present study aims to elucidate if common ecological and evolutionary processes lead to congruence in the genetic structure of Linckia laevigata and Thyca crystallina populations from the Indo-Malay Archipelago. The genetic marker used for both species in the present study is the cytochrome c oxidase I gene (COI), which is suitable to investigate the genetic population structure of starfishes (e.g. Harley et al. 2006) and snails (e.g. Reid et al. 2006).

\section{MATERIALS AND METHODS}

Sampling. Tissue samples from 270 specimens of the blue starfish Linckia laevigata and 324 specimens of its ectoparasite, the snail Thyca crystallina, were collected during several field trips from 2004 to 2007 at 24 sample sites across the Indo-Malay Archipelago (Fig. 1A,C, Table 1). Several colour morphs of L. laevigata are known, such as blue, orange, green, and violet. Since genetic studies indicated that colour variation is congruent to genetic variation (Williams \& Benzie 1998) and that species boundaries in Linckia are difficult to define (Williams 2000), only blue colour morphs were analysed. Tissue samples were preserved in $>96 \%$ ethanol and later stored at $4{ }^{\circ} \mathrm{C}$.

DNA extraction, amplification and sequencing. Extraction of genomic DNA from both species was done with the Chelex method, following the protocol of Walsh et al. (1991). A fragment of the mitochondrial COI gene was used for both species as molecular marker and amplified with the primers from Folmer et al. (1994). PCR was conducted in a volume of $50 \mu \mathrm{l}$ and contained $2 \mu \mathrm{l}$ DNA template, $10 \mathrm{mM}$ Tris- $\mathrm{HCl}(\mathrm{pH}$ 9), $50 \mathrm{mM} \mathrm{KCl}, 4 \mathrm{mM} \mathrm{MgCl} 2,0.4 \mu \mathrm{M}$ of each primer, $0.2 \mathrm{mM}$ dNTPs, $2 \mu \mathrm{l}$ BSA $(2 \mathrm{mg} / \mathrm{ml})$ and $1 \mathrm{U}$ Taq polymerase. The following temperature profile was used for the PCR: $94^{\circ} \mathrm{C}$ for $5 \mathrm{~min}$, followed by 35 cycles of $1 \mathrm{~min}$ at $94^{\circ} \mathrm{C}, 1.5 \mathrm{~min}$ at $45^{\circ} \mathrm{C}$ and $1 \mathrm{~min}$ at $72^{\circ} \mathrm{C}$. Final extension was conducted at $72^{\circ} \mathrm{C}$ for $5 \mathrm{~min}$. The PCR products were purified using the QIAquick spin column PCR purification kit (Qiagen), following the manufacturer's protocol. Sequencing was done using the DyeDeoxy terminator chemistry (PE Biosystem) and an automated sequencer (ABI PRISM 310 and 3100, Applied Biosystems). New primers were designed for cycle sequencing in Linckia laevigata (Linckia Seq Frw [forward]: 5'-AAA ATC AGA ATA AGT GCT GGA-3'; Linckia Seq Rev [reverse]: 5'-TTT GGA GCT TGA GCT GGA ATG-3') and Thyca crystallina (Thyca Seq Frw [forward]: 5'-TAT TGT AAC TGC TCA TGC TTT TG-3').

Genetic diversity. Sequences were edited with the programmes Sequence Navigator (version 1.0.1, Applied Biosystems) or Seqman (version 4.05, DNAStar). They were translated to amino acids with the program Bioedit (version 7.0.9.0, Hall 1999) in order to exclude mistakes in sequencing and to verify if a functional mitochondrial DNA sequence was obtained and not a nuclear pseudogene. Multiple alignment was done using Clustal W (Thompson et al. 1994) as implemented in the software Bioedit. Haplotype diversity $h$ (Nei 1987) and nucleotide diversity (Nei \& Jin 1989) were calculated with the programme Arlequin (http://cmpg.unibe.ch/software/arlequin3, version 3.11; Excoffier et al. 2005). 

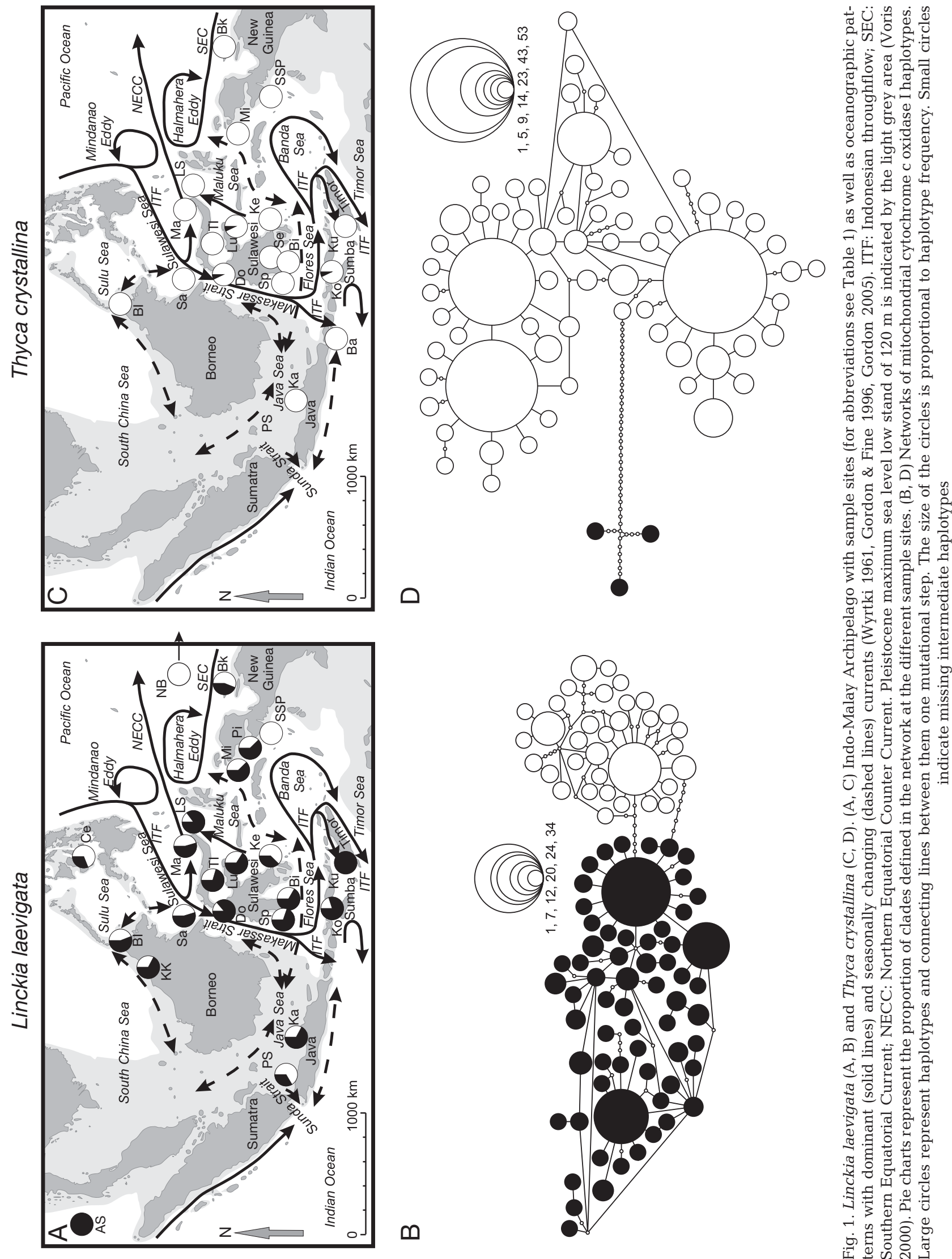


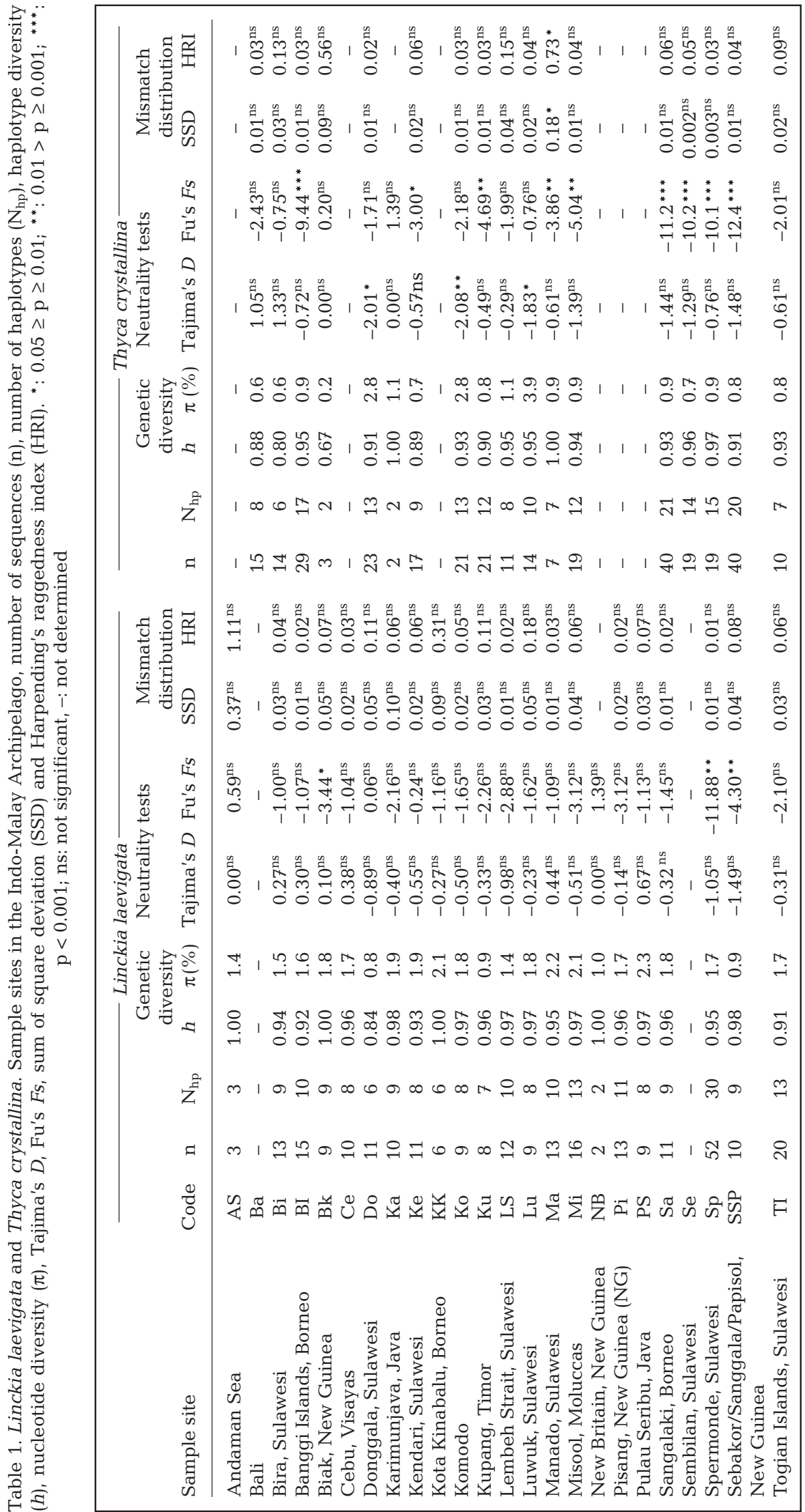


Historical demography. The null hypothesis of neutral evolution of the marker was tested using Tajima's $D$-test (Tajima 1989) and Fu's Fs-test (Fu 1997). Negative Tajima's $D$-values can indicate selection, but also population bottlenecks or population expansions (Tajima 1989). The historical demography was analysed by mismatch distribution (Schneider \& Excoffier 1999) of the sum of square deviation (Rogers \& Harpending 1992) and Harpending's raggedeness index (Harpending 1994), thus testing the model of sudden population expansion (Rogers 1995). The mismatch distribution, which is the distribution of the observed differences between haplotypes, is multimodal in populations under a demographic equilibrium and unimodal if a recent and fast demographic expansion of the population has taken place. All tests were conducted with 10000 permutations as implemented in the programme Arlequin.

Genetic population structure and connectivity. Analysis of molecular variance (AMOVA; Excoffier et al. 1992) and pairwise $\phi_{\mathrm{ST}}$-values were used to test for significance of population structure. Both statistical calculations were carried out using the software Arlequin, applying the Tamura-Nei substitution model and gamma shape parameters of 0.3 (Linckia laevigata) and 0.2 (Thyca crystallina), based on the result obtained with the programmes PAUP (version 4.0b10; Swofford 1998) and Modeltest (version 3.7; Posada \& Crandall 1998). Several groupings of L. laevigata and T. crystallina populations were tested in a hierarchical AMOVA $\phi_{\mathrm{CT}}$, considering the geography of the region.

Since the coverage of sample sites for the 2 species was different, AMOVA was also conducted with reduced data sets, containing only sites for which samples of both species were available. This was done in order to test if differences in the genetic population structure were due to unequal sampling. Based on an analysis with Modeltest, a gamma shape parameter of 0.2 and the Tamura-Nei substitution model were applied for both species.

Haplotype networks were calculated with the programme TCS (version 1.21; Clement et al. 2000). Clades were defined by the highest number of mutational steps found in a network.

\section{RESULTS}

\section{Genetic diversity}

Sequence alignments of the COI fragment of 473 and $401 \mathrm{bp}$ lengths were obtained from 270 individuals of Linckia laevigata and 324 individuals of Thyca crystallina, respectively (Table 1). The observed number of haplotypes was 101 in L. laevigata and 68 in T. crystal- lina. The sequences of these haplotypes are available at the EMBL sequence database under the accession numbers FN392698-FN392798 (L. laevigata) and FN392799-FN392866 (T. crystallina).

Genetic diversity within each population of Linckia laevigata showed high levels of haplotype and nucleotide diversity, ranging from 0.84 in the population from Donggala (Sulawesi) to 1.00 in Kota Kinabalu (Borneo), New Britain, and Biak (both New Guinea). Nucleotide diversity was between $0.8 \%$ in Donggala and $2.3 \%$ in Pulau Seribu (Java Sea) (Table 1).

In Thyca crystalina, haplotype diversity was similar to Linckia laevigata, but nucleotide diversity was generally lower in most populations. Haplotype diversity in T. crystallina ranged between 0.80 in Bira (Sulawesi) to 1.00 in Karimunjava (Java Sea) and Manado (Sulawesi). Nucleotide diversity was between 0.2 in Donggala and $3.9 \%$ in Luwuk (Sulawesi) (Table 1).

\section{Historical demography}

The null hypothesis of neutral evolution of the COI marker in Linckia laevigata was not rejected for all sample sites based on Tajima's D-test, whereas the results of Fu's Fs-test rejected the null hypothesis for 3 sites. In Thyca crystallina, Tajima's D-test rejected the null hypothesis of neutral evolution in 3 cases; Fu's Fstest rejected the null hypothesis in half of the cases. However, this could indicate population expansion in both species, which is supported by the mismatch distribution analysis and Rogers' test of sudden population expansion, except in the population of T. crystallina from Manado (Sulawesi) (Rogers 1995; Table 1).

\section{Genetic population structure and connectivity}

The evolutionary relationships among 101 Linckia laevigata haplotypes and 68 Thyca crystallina haplotypes are presented in networks, showing 2 clades in both L. laevigata (Fig. 1B) and T. crystallina (Fig. 1D). The distribution of clades across the Indo-Malay Archipelago is presented in Fig. 1A, C, respectively.

In Linckia laevigata, the 2 clades are separated by 6 mutational steps. The samples from the sites in the Andaman Sea and in Timor consisted only of haplotypes from the black clade, whereas the samples from New Britain and the southwestern coast of New Guinea were presented only by haplotypes of the white clade. All other sites showed haplotypes from both clades, $>75 \%$ of them dominated by the black clade (Fig. 1A). AMOVA revealed a low fixation index, but significant genetic population structure $\left(\phi_{\mathrm{ST}}=0.03\right.$, $\mathrm{p}=0.029$ ) across the Indo-Malay Archipelago. How- 
ever, no significant genetic structure was found among sites in the Spermonde Archipelago $\left(\phi_{\mathrm{ST}}=0.01, \mathrm{p}=\right.$ 0.39). Pairwise $\phi_{\mathrm{ST}}$-values between sample sites revealed homogeneity among most of them; only $13 \%$ showed significant differences (data not shown). A hierarchical AMOVA with several groupings of sample sites was carried out, but only the following rejected the hypothesis of panmixing $\left(\phi_{\mathrm{CT}}=0.07, \mathrm{p}=0.003\right)$ : (1) Eastern Indian Ocean (Andaman Sea and Kupang), (2) Western Pacific (Biak, New Britain) and (3) all remaining sites in the central Indo-Malay Archipelago.

The 2 clades in Thyca crystallina were separated by 35 mutational steps (Fig. 1D). All sample sites were dominated by the white clade, and haplotypes of the black clade were only present at sample sites from the central Indo-Malay Archipelago (Komodo, Donggala and Luwuk) (Fig. 1C). AMOVA revealed a very low and nonsignificant fixation index $\left(\phi_{\mathrm{ST}}=0.005, \mathrm{p}=0.24\right)$ across the Indo-Malay Archipelago. Similar to Linckia laevigata, most pairwise $\phi_{\mathrm{ST}}$-values were not significant in T. crystallina and only $10 \%$ showed restricted gene flow (data not shown). A hierarchical AMOVA did not show any significant groupings of sample sites.

AMOVA of data sets reduced to sites for which samples of both species were available did not show significant population structures for Linckia laevigata $\left(\phi_{\mathrm{ST}}=\right.$ $0.02, \mathrm{p}=0.09$ ) or Thyca crystallina $\left(\phi_{\mathrm{ST}}=0.002, \mathrm{p}=0.33\right)$.

\section{DISCUSSION}

\section{Genetic diversity}

Most populations of the starfish Linckia laevigata and its ectoparasite Thyca crystallina showed high levels of haplotype diversity. These values are comparable to other studies on invertebrate species in the Indo-Malay Archipelago using COI as a marker, such as the giant clams Tridacna crocea (DeBoer et al. 2008, Kochzius \& Nuryanto 2008) and Tridacna maxima (Nuryanto \& Kochzius 2009), as well as the mantis shrimp Haptosquilla pulchella (Barber et al. 2002). Nucelotide diversity was generally $>1 \%$ in $L$. laevigata, but $<1 \%$ in T. crystallina, a pattern also observed in another study (Crandall et al. 2008a). Levels of nucleotide diversity $<1 \%$ were also detected in giant clams (DeBoer et al. 2008, Kochzius \& Nuryanto 2008, Nuryanto \& Kochzius 2009) and mantis shrimp (Barber et al. 2002).

\section{Historical demography}

The null hypothesis of neutral evolution was rejected by Tajima's $D$ and Fu's $F$ s neutrality tests at some sample sites (Table 1), but these tests cannot distinguish be- tween selection and changes in population size. Demographic growth was indicated by mismatch distribution analysis and Rogers' test of sudden population expansion (Rogers \& Harpending 1992, Rogers 1995). Since large shelf areas, such as the Sunda shelf between Java and Borneo, fell dry during several Pliocene and Pleistocene glacial sea level low stands, the extent of coral reef habitats in the Indo-Malay Archipelago and, consequently, population sizes were reduced (Fig. 1). Because of rising sea level in interglacial periods, new habitats could be colonised, resulting in a demographic and spatial population expansion. Signals of population expansion in the Indo-Malay Archipelago have also been observed in another study on Linckia laevigata and Thyca crystallina (Crandall et al. 2008a), as well as giant clams (Kochzius \& Nuryanto 2008, Nuryanto \& Kochzius 2009) and the clownfish Amphiprion ocellaris (Timm \& Kochzius 2008).

\section{Genetic population structure and connectivity}

Linckia laevigata showed a rather weak, but significant population structure $\left(\phi_{\mathrm{ST}}=0.03\right)$ across the IndoMalay Archipelago. However, analysis of the reduced data set indicated panmixing $\left(\phi_{\mathrm{ST}}=0.02\right)$. This is probably due to the fact that populations from the margins of the study area, such as the Eastern Indian Ocean, Eastern New Guinea and the Philippines, have been removed. This indicates that there are high levels of gene flow in the central part of the Indo-Malay Archipelago and that populations at the margin are less well connected to the centre. Several studies based on allozyme data also showed low levels of genetic heterogeneity in $L$. laevigata on different geographic scales, ranging from panmixing (Williams \& Benzie 1993, 1996) to significant but shallow genetic structures (Williams \& Benzie 1998, Magsino et al. 2000, Juinio-Meñez et al. 2003). On large geographic scales in the Indo-West Pacific, PCR-restriction fragment length polymorphism analysis of mitochondrial DNA revealed a more prominent genetic population structure in L. laevigata (Williams \& Benzie 1997, 1998) compared to the present study. Other invertebrate species, such as giant clams (DeBoer et al. 2008, Kochzius \& Nuryanto 2008, Nuryanto \& Kochzius 2009) and mantis shrimp (Barber et al. 2002), showed much higher $\phi_{\mathrm{ST}}$-values for the COI marker than L. laevigata in the present study. The less prominent genetic population structure in L. laevigata could be due to substantial gene flow resulting from its high dispersal potential (pelagic larval duration [PLD] = $22 \mathrm{~d}_{i}$ Yamaguchi 1973). In contrast, the PLD for giant clams is only $9 \mathrm{~d}$ (Lucas 1988). A much stronger genetic population structure was also revealed based on other genetic 
markers in clownfish $\left(\phi_{\mathrm{ST}}=0.24 ;\right.$ Timm \& Kochzius 2008) with a PLD of 8 to 12 d (Fautin \& Allen 1994), and a mushroom coral $\left(\phi_{\mathrm{ST}}=0.26\right.$; Knittweis et al. 2009) with a PLD of $3 \mathrm{~d}$ (Abe 1937).

The significant genetic structure was more pronounced in the hierarchical analysis $\left(\phi_{\mathrm{CT}}=0.07\right)$ with the following grouping: (1) Eastern Indian Ocean, (2) central Indo-Malay Archipelago and (3) Western Pacific. This pattern of a discontinuity between the Indian and Pacific Oceans was more or less similar in the giant clams Tridacna crocea (DeBoer et al. 2008, Kochzius \& Nuryanto 2008) and Tridacna maxima (Nuryanto \& Kochzius 2009), the clownfish Amphiprion ocellaris (Timm \& Kochzius 2008) and the mushroom coral Heliofungia actiniformis (Knittweis et al. 2009). In another study (Crandall et al. 2008a) on Linckia laevigata, a genetic break between grouped sites from the (1) Eastern Indian Ocean and (2) the central Indo-Malay Archipelago, as well as the Western Pacific, showed the same $\phi_{\mathrm{CT}}$-value as the present analysis. Earlier large-scale studies using COI sequences also detected a genetic differentiation between the 2 ocean basins (Williams 2000, Williams et al. 2002). Such a break was also detected in the crown-of-thorns starfish Acanthaster planci based on allozymes (Benzie 1999) and COI sequences (Vogler et al. 2008).

This genetic break between the 2 ocean basins was also apparent in the distribution of the black and white clades in Linckia laevigata. Two populations in the Indian Ocean (Andaman Sea and Kupang) harboured only individuals carrying haplotypes of the black clade, whereas the populations in the Western Pacific either only consisted of white clade haplotypes (New Britain) or were dominated by them (Biak and Cebu). These clades showed a strong mixing in the central Indo-Malay Archipelago, but the black clade showed a higher frequency in most of the populations (Fig. 1). In contrast to other species that show a main route of dispersal from the Western Pacific into the Eastern Indian Ocean along the path of the ITF (Kochzius \& Nuryanto 2008, Timm \& Kochzius 2008, Knittweis et al. 2009, Nuryanto \& Kochzius 2009), L. laevigata seems to enter the Western Pacific from the Eastern Indian Ocean against the ITF. This pattern can also be observed in other studies on L. laevigata (Williams et al. 2002, Crandall et al. 2008a). Dispersal against the strong ITF that transports up to 19 million $\mathrm{m}^{3}$ of water per second from the Pacific to the Indian Oceans (Gordon \& Fine 1996, Gordon 2005) might be facilitated by seasonally changing currents in Makassar Strait along the coast of Borneo, which are directed to the north in October (Wyrtki 1961; Fig. 1). This coincides with the spawning period of L. laevigata in October on Heron Island, Great Barrier Reef (Laxton 1974).

Neither an AMOVA nor hierarchical AMOVA indicated restricted gene flow in Thyca crystallina across the Indo-Malay Archipelago. This species produces in extended breeding periods probably planktonic larvae (Elder 1979) with a high dispersal potential, which is supported by the shallow genetic population structure. This lack of a genetic break between the Indian and Pacific Oceans has also been shown for other species, such as the bigeye tuna Thunnus obesus (Alvarado Bremer et al. 1998, Chow et al. 2000), the swordfish Xiphias gladius (Chow et al. 1997), the tasslefish Polynemus sheridani (Chenoweth \& Hughes 2003), the snails Echinolittorina reticulata (Reid et al. 2006) and Nerita plicata (Crandall et al. 2008b), as well as the sea urchin Diadema savignyi (Lessios et al. 2001). However, mechanisms that lead to genetic homogeneity across the Indo-Malay Archipelago are expected to be different among species.

Even though no significant genetic population structure was observed, Thyca crystallina showed 2 highly divergent clades that were separated by 35 mutational steps (Fig. 1D). This deep divergence might indicate a cryptic species, but this hypothesis should be verified in an integrative taxonomy approach, including genetic, morphological and ecological data. Such an approach revealed, for instance, a new species of giant clam Tridacna costata in the Red Sea (Richter et al. 2008). Similar deep divergences have been observed in the giant clams Tridacna crocea (DeBoer et al. 2008, Kochzius \& Nuryanto 2008) and Tridacna maxima (Nuryanto \& Kochzius 2009) across the Indo-Malay Archipelago. It is possible that these 2 divergent clades in T. crystallina were affiliated to the Indian and Pacific Oceans, respectively, caused by sea level low stands. After the rise in sea level, the 2 clades came into contact again and the black clade was replaced by the white clade. Even though Linckia laevigata and Thyca crystallina are codistributed due to a host-parasite relationship, they showed differences in their genetic population structure. This is probably caused by differences in their mode of reproduction, showing that it is not only common ecological and evolutionary processes that are important in shaping the genetic population structure of the 2 species.

Acknowledgements. We thank the institutions and individuals that have made this study possible: German Federal Ministry of Education and Research (BMBF, grant nos. 03F0390B and 03F0427B), which funded this study in the framework of the joint German-Indonesian project SPICE (Science for the Protection of Indonesian Coastal Marine Ecosystems); German Academic Exchange Service (DAAD) for supporting A.N.; Centre for Tropical Marine Ecology (Bremen, Germany) for project coordination, especially C. Richter; GEO Magazine (Hamburg, Germany) for financing the research to Misool and New Guinea; G. Heiss and U. Krumme for providing samples; colleagues from Universitas Hasanuddin (Makassar, Indonesia) for logistical support in Spermonde, especially J. Jompa; and anonymous reviewers for constructive comments. The SPICE 
project is conducted and permitted under the governmental agreement between the German Federal Ministry of Education and Research (BMBF) and the Indonesian Ministry for Research and Technology (RISTEK), Indonesian Institute of Sciences (LIPI), Indonesian Ministry of Maritime Affairs and Fisheries (DKP), and Agency for the Assessment and Application of Technology (BPPT). This work was carried out in cooperation with Hassanuddin University (UNHAS, Makassar, Indonesia), Agricultural University Bogor (IPB, Bogor, Indonesia), and Jenderal Soedirman University (Purwokerto, Indonesia).

\section{LITERATURE CITED}

Abe N (1937) Post-larval development of Fungia actiniformis. Palao Trop Biol Stn Stud 1:73-79

Alvarado Bremer JR, Stequert B, Robertson NW, Ely B (1998) Genetic evidence for inter-oceanic subdivision of bigeye tuna (Thunnus obesus Lowe) populations. Mar Biol 132: $547-557$

Avise JC (2000) Phylogeography: the history and formation of species. Harvard University Press, Cambridge, MA

Barber PH, Palumbi SR, Erdmann MV, Moosa MK (2002) Sharp genetic breaks among populations of Haptosquilla pulchella (Stomatopoda) indicate limits to larval transport: patterns, causes and consequences. Mol Ecol 11:659-674

Benzie JAH (1999) Major genetic differences between crownof-thorns starfish (Acanthaster planci) populations in the Indian and Pacific Oceans. Evolution 53:1782-1795

Bermingham E, Moritz C (1998) Comparative phylogeography: concepts and applications. Mol Ecol 7:367-369

Bouillon J, Jangoux M (1984) Note sur l'association entre le mollusque parasite Thyca crystallina (Gould) (Gasteropoda, Prosobranchia) et l'astéride Linckia laevigata (L.) (Echinodermata) sur le récif de l'île de Laing (Papouasie-Nouvelle Guinée). Ann Soc R Zool Belg 114: 249-256

Briggs JC (1999) Coincident biogeographic patterns: IndoWest Pacific Ocean. Evolution 53:326-335

> Cane MA, Molnar P (2001) Closing of the Indonesian seaway as a precursor to east African aridification around 3-4 million years ago. Nature 411:157-162

Chao SM (1999) Revision of Taiwan starfish (Echinodermata: Asteroidea), with description of ten new records. Zool Stud 38:405-415

> Chenoweth SF, Hughes JM (2003) Oceanic interchange and nonequilibrium population structure in the estuarine dependent Indo-Pacific tasselfish, Polynemus sheridani. Mol Ecol 12:2387-2397

Chow S, Okamoto H, Uozumi Y, Takeuchi Y, Takeyama H (1997) Genetic stock structure of the swordfish (Xiphias gladius) inferred by PCR-RFLP analysis of the mitochondrial DNA control region. Mar Biol 127:359-367

> Chow S, Okamoto H, Miyabe N, Hiramatsu K, Barut N (2000) Genetic divergence between Atlantic and Indo-Pacific stocks of bigeye tuna (Thunnus obesus) and admixture around South Africa. Mol Ecol 9:221-227

> Clement M, Posada D, Crandall KA (2000) TCS: a programme to estimate gene genealogies. Mol Ecol 9:1657-1660

> Crandall ED, Jones ME, Muñoz MM, Akinronbi B, Erdmann MV, Barber PH (2008a) Comparative phylogeography of two seastars and their ectosymbionts within the Coral Triangle. Mol Ecol 17:5276-5290

> Crandall ED, Frey MA, Grosberg RK, Barber PH (2008b) Contrasting demographic history and phylogeographical patterns in two Indo-Pacific gastropods. Mol Ecol 17:611-626

> Criscione CD (2008) Parasite co-structure: broad and local scale approaches. Parasite 15:439-443
DeBoer TS, Subia MD, Ambariyanto, Erdmann MV, Kovitvongsa K, Barber PH (2008) Phylogeography and limited genetic connectivity in the endangered giant boring clam, Tridacna crocea, across the Coral Triangle. Conserv Biol 22:1255-1266

Egloff DA, Smouse D, Pembroke E (1988) Penetration of the radial hemal and perihemal system of Linckia laevigata (Asteroidea) by the proboscis of Thyca crystallina, an ectoparasitic gastropod. Veliger 30:342-346

- Elder HY (1979) Studies on the host parasite relationship between the parasitic prosobranch Thyca crystallina and the asteroid starfish Linckia laevigata. J Zool 187: 369-391

- Excoffier L, Smouse PE, Quattro JM (1992) Analysis of molecular variance inferred from metric distances among DNA haplotypes: application to human mitochondrial DNA restriction data. Genetics 131:479-491

Excoffier L, Laval G, Schneider S (2005) Arlequin (version 3.0): an integrated software package for population genetics data analysis. Evol Bioinform Online 1:47-50

Fautin DG, Allen GR (1994) Anemonenfische und Ihre Wirte. Tetra-Verlag, Melle

Folmer O, Black M, Lutz R, Vrijenhoek R (1994) DNA primers for amplification of mitochondrial cytochrome c oxidase subunit I from metazoan invertebrates. Mol Mar Biol Biotechnol 3:294-299

> Froukh T, Kochzius M (2008) Species boundaries and evolutionary lineages in the blue green damselfishes Chromis viridis and C. atripectoralis (Pomacentridae). J Fish Biol 72:451-457

> Fu YX (1997) Statistical test of neutrality of mutations against population growth, hitchhiking and background selection. Genetics 147:915-925

Gordon AL (2005) Oceanography of the Indonesian seas and their throughflow. Oceanography 18:14-27

> Gordon AL, Fine RA (1996) Pathways of water between the Pacific and Indian Oceans in the Indonesian seas. Nature 379:146-149

Hall R (1998) The plate tectonics of Cenozoic SE Asia and the distribution of land and sea. In: Hall R, Holloway JD (eds) Biogeography and geological evolution of SE Asia. Backhuys Publishers, Leiden, p 99-131

Hall TA (1999) BioEdit: a user-friendly biological sequence alignment editor and analysis program for Windows 95/98/NT. Nucleic Acids Symp Ser 41:95-98

- Harley CDG, Pankey MS, Wares JP, Grosberg RK, Wonham MJ (2006) Color polymorphism and genetic structure in the sea star Pisaster ochraceus. Biol Bul 211:248-262

Harpending HC (1994) Signature of ancient population growth in a low-resolution mitochondrial DNA mismatch distribution. Hum Biol 66:591-600

Hoeksema BW (2007) Delineation of the Indo-Malayan centre of maximum marine biodiversity: the coral triangle. In: Renema W (ed) Biogeography, time and place: distributions, barriers and islands. Topics in Geobiology, Vol 29. Springer, Dordrecht, p 117-178

Janssen HH (1985) Three epizoic gastropods from Malaysia and the Philippines. Parasitol Res 71:553-560

Juinio-Meñez MA, Magsino RM, Ravago-Gotanco R, Yu ET (2003) Genetic structure of Linckia laevigata and Tridacna crocea populations in the Palawan shelf and shoal reefs. Mar Biol 142:717-726

Knittweis L, Krämer WE, Timm J, Kochzius M (2009) Genetic structure of Heliofungia actiniformis (Scleractinia: Fungiidae) populations in the Indo-Malay Archipelago: implications for live coral trade management efforts. Conserv Genet 10:241-249 
Kochzius M, Nuryanto A (2008) Strong genetic population structure in the boring giant clam Tridacna crocea across the Indo-Malay Archipelago: implications related to evolutionary processes and connectivity. Mol Ecol 17: 3775-3787

Kochzius M, Söller R, Khalaf MA, Blohm D (2003) Molecular phylogeny of the lionfish genera Dendrochirus and Pterois (Scorpaenidae, Pteroinae) based on mitochondrial DNA sequences. Mol Phylogenet Evol 28:396-403

Krantz DE (1991) A chronology of Pliocene sea-level fluctuations: the US middle Atlantic coastal plain record. Quat Sci Rev 10:163-174

Laxton JH (1974) A preliminary study of the biology and ecology of the blue starfish Linckia laevigata (L.) on the Australian Great Barrier Reef and an interpretation of its role in the coral reef ecosystem. Biol J Linn Soc 6:47-64

Lessios HA, Kessing BD, Pearse JS (2001) Population structure and speciation in tropical seas: global phylogeography of the sea urchin Diadema. Evolution 55: 955-975

Lucas JS (1988) Giant clams: description, distribution and life history. In: Copland JW Lucas JS (eds) Giant clams in Asia and the Pacific. Australian Centre for International Agricultural Research, Canberra, p 21-32

Magsino RM, Juinio-Meñez MAR, Ravago RV (2000) Development and application of genetic markers for population structure analysis of the blue coral reef starfish, Linckia laevigata (Linn.) (Echinodermata: Asteroidea). Sci Diliman 12:10-16

Nei M (1987) Molecular evolutionary genetics. Columbia University Press, New York

$>$ Nei M, Jin L (1989) Variances of the average numbers of nucleotide substitutions within and between populations. Mol Biol Evol 6:290-300

Nuryanto A, Kochzius M (2009) Highly restricted gene flow and deep evolutionary lineages in the giant clam Tridacna maxima. Coral Reefs 28:607-619

Posada D, Crandall KA (1998) Modeltest: testing the model of DNA substitution. Bioinformatics 14:817-818

Reid DG, Lal K, Mackenzie-Dodds J, Kaligis F, Littlewood DTJ, Williams ST (2006) Comparative phylogeography and species boundaries in Echinolittorina snails in the central Indo-West Pacific. J Biogeogr 33:990-1006

Richter C, Roa-Quiaoit H, Jantzen C, Al-Zibdah M, Kochzius $\mathrm{M}$ (2008) Collapse of a new living species of giant clam in the Red Sea. Curr Biol 18:1349-1354

Rogers AR (1995) Genetic evidence for Pleistocene population expansion. Evolution 49:608-615

Rogers AR, Harpending H (1992) Population growth makes waves in the distribution of pairwise genetics differences. Mol Biol Evol 9:552-569

Rohling EJ, Fenton M, Jorissen FJ, Bertrand P, Ganssen G, Caulet JP (1998) Magnitudes of sea-level lowstands of the past 500,000 years. Nature 394:162-165

Schneider S, Excoffier L (1999) Estimation of past demographic parameters from distribution of pairwise differences when the mutation rates vary among sites: application to human mitochondrial DNA. Genetics 152: 1079-1089

Siddall M, Rohling EJ, Almogi-Labin A, Hemleben C," Meischner D, Schmelzer I, Smeed DA (2003) Sea-level fluctuations during the last glacial cycle. Nature 423:853-858

Sloan NA, Clark AM, Taylor JD (1979) The echinoderms of Aldabra and their habitats. Bull Br Mus (Nat Hist) 37: 81-128

Swofford DL (1998) PAUP*: phylogenetic analysis using parsimony (and other methods). Version 4.0b10. Sinauer \& Associates, Sunderland, MA
Tajima F (1989) Statistical method for testing the neutral mutation hypothesis by DNA polymorphism. Genetics 123:585-595

Thompson JD, Higgins DG, Gibson TJ (1994) Clustal W: improving the sensitivity of progressive multiple sequence alignments through sequence weighting, position specific gap penalties and weight matrix choice. Nucleic Acids Res 22:4673-4680

Timm J, Kochzius M (2008) Geological history and oceanography of the Indo-Malay Archipelago shape the genetic population structure in the false clown anemonefish (Amphiprion ocellaris). Mol Ecol 17:3999-4014

Timm J, Figiel M, Kochzius M (2008) Contrasting patterns in species boundaries and evolution of anemonefishes (Amphiprioninae, Pomacentridae) in the centre of marine biodiversity. Mol Phylogenet Evol 49:268-276

Troncoso JS, Van Goethem J (1998) Nuevos datos sobre la asociación de Stilifer linckiae y Thyca crystallina (Mollusca, Eulimidae) con Linckia laevigata (Linnaeus, 1758) (Echinodermata, Asteroidea) en la Isla de Laing (Bahía de Hansa, Provincia de Madang, N de Papua-Nueva Guinea). NACC Nova Acta Cient Compostel Biol 8: 201-208

> Vogler C, Benzie J, Lessios H, Barber P, Wörheide G (2008) A threat to coral reefs multiplied? Four species of crown-ofthorns starfish. Biol Lett 4:696-699

- Voris HK (2000) Maps of Pleistocene sea levels in Southeast Asia: shorelines, river systems and time duration. J Biogeogr 27:1153-1167

Walsh PS, Metzger DA, Higushi R (1991) Chelex 100 as a medium for simple extraction of DNA for PCR-based typing from forensic material. Biotechniques 10:506-513

Warén A (1980) Revision of the genera Thyca, Stilifer, Scalenostoma, Mucronalia and Echineulima (Mollusca, Prosobranchia, Eulimidae). Zool Scr 9:187-210

Williams ST (2000) Species boundaries in the starfish genus Linckia. Mar Biol 136:137-148

Williams ST, Benzie JAH (1993) Genetic consequences of long larval life in the starfish Linckia laevigata (Echinodermata: Asteroidea) on the Great Barrier Reef. Mar Biol 117:71-77

Williams ST, Benzie JAH (1996) Genetic uniformity of widely separated populations of the coral reef starfish Linckia laevigata from the East Indian and West Pacific Oceans, revealed by allozyme electrophoresis. Mar Biol 126: 99-107

Williams ST, Benzie JAH (1997) Indo-West Pacific patterns of genetic differentiation in the high-dispersal starfish Linckia laevigata. Mol Ecol 6:559-573

Williams ST, Benzie JAH (1998) Evidence of a biogeographic break between populations of a high dispersal starfish: congruent regions within the Indo-West Pacific defined by color morphs, mtDNA, and allozyme data. Evolution 52:87-99

Williams ST, Jara J, Gomez N, Knowlton N (2002) The marine Indo-West Pacific break: contrasting the resolving power of mitochondrial and nuclear genes. Integr Comp Biol 42:941-952

Wyrtki K (1961) Physical oceanography of the Southeast Asian waters. University of California, La Jolla

Yamaguchi M (1973) Early life histories of coral reef asteroids, with special reference to Acanthaster planci (L.). In: Jones OA, Endean R (eds) Biology and geology of coral reefs. Academic Press, New York and London, p 369-387

Yamaguchi M (1977) Population structure, spawning, and growth of the coral reef asteroid Linckia laevigata (Linnaeus). Pac Sci 31:13-30 